Jure Gašparič

\title{
Slovenian Socialist Parliament on the Eve of the Dissolution of the Yugoslav Federation: A Feeble "Ratification Body" or Important Political Decision-Maker?
}

\author{
IZVLE ČEK \\ SLOVENSKI SOCIALISTIČNI PARLAMENT NA PREDVEČER RAZPADA \\ JUGOSLOVANSKE FEDERACIJE - BLEDO "RATIFIKACIJSKO TELO" \\ ALI VAŽEN POLITIČNI ODLOČEVALEC?
}

Skupšcina socialistične republike Slovenije je bila še leta 1986, na predvečer razpada jugoslovanske federacije, precej dolgočasen organ, zaprt v uradniško-formalistične okvirje. Sestavljali so jo na specifičen posredni način izvoljeni neprofesionalni delegati brez večjega družbenega vpliva. Toda prav ta skupščina je nato nekaj let kasneje sprejela več ključnih odločitev, ki so uvedle večstrankarski sistem, elemente tržnega gospodarstva in okrepile položaj republike. Zdi se, da je skupšcina takrat postala prvi faktor tranzicije in da je prav ona zamajala jugoslovansko federacijo. Toda taka ocena se vendarle ni uveljavila. Njena vloga deluje nejasno. Izhajajoč iz tega avtor v prispevku išče odgovor na vprašanje: Kakšen organ je bila socialistična skupščina? Pri tem najprej predstavi genezo jugoslovanskega skupšcinskega sistema in njegove temeljne značilnosti, nato pa obravnava tri različne ravni oz. možne poglede na skupščino: pravno raven, percepcijsko raven (kako so ljudje dojemali skupšcino) in raven notranjih mehanizmov (kako se je spreminjala parlamentarna razprava).

Ključne besede: socialistični parlament, Jugoslavija, Slovenija, razpad, 1989

\section{ABSTRACT}

In 1986, on the eve of the dissolution of the Yugoslav Federation, the Assembly of the Socialist Republic of Slovenia was a rather boring authority, restricted to the bureaucratic and formalist framework. It consisted of nonprofessional delegates without significant social influence, elected in a specific indirect manner. However, it was this very Assembly that passed several key decisions a few years later, leading to the introduction of a multiparty system and elements of market economy, as well as strengthening the position of the republic. It seems that at the time this Assembly became

* senior researcher, PhD, Institute of Contemporary History, Kongresni trg 1, 1000 Ljubljana, Slovenia, jure.gasparic@inz.si 
the primary factor of transition and that it was this very institution that destabilised the Yugoslav federation. However, such an evaluation has nevertheless not asserted itself. The role of the socialist Assembly appears vague. Consequently the author, in his contribution, seeks to answer the following question: What sort of an authority body was the socialist Assembly? Initially the author presents the genesis of the Yugoslav Assembly system and its basic characteristics, and then he explores the three different levels or possible outlooks on the Assembly: legal level, perceptual level (how people saw the Assembly), and the level of internal mechanisms (how the parliamentary discussions changed).

Keywords: socialist Parliament, Yugoslavia, Slovenia, dissolution, 1989

\section{To Be President of the Socialist Assembly is a "Comfortable Function"}

In April 1986 a relatively young Slovenian politician with quite impressive political mileage Miran Potrč (among other things he had been the President of the Labour Union Association of Yugoslavia a few years earlier; at that time, in terms of protocol, he was in the $13^{\text {th }}$ place in the Yugoslav hierarchy) was elected as President of the Socialist Assembly of the Republic of Slovenia. Formally this function was very important as well, as in Slovenia only the President of the Republic was superior to him. However, as Potrč wrote in his memoirs, "the President of the Executive Committee, but especially the President of the Central Committee of the League of Communists of Slovenia and occasionally also the President of the Socialist Alliance of the Working People had a greater influence on the situation in the society." ${ }^{1}$ To put it differently, Potrč was inferior to the Head of Government, Head of the Party, and Head of a specific "socio-political organisation", the Socialist Alliance of the Working People, whose extensive jurisdiction and open-door policy gave Yugoslav socialism the appearance of democracy. Therefore to be President of the Assembly was, "under normal circumstances", a "comfortable function, as it mostly involved the responsibility for work organisation and prompt decision-making, and even in this regard the President of the Assembly could consult three Presidents of Chambers and a well-organised professional service, while he was not directly responsible for the content of the decisions themselves." ${ }^{2}$ In 1986 the circumstances in the state were still "normal".

The economic crisis might have been troubling the country for quite a long time before and no efficient political solutions were on the horizon, but at the same time the spring of 1986 was the time when the Memorandum of the Serbian Academy of Science and Arts - a "Greater Serbian" national programme, which caused so much unrest in Yugoslavia in September 1986 - had not been published yet. Furthermore, the ascent of the Serbian leader Slobodan Milošević, accompanied with a series of

1 Miran Potrč, Klic k razumu: spomini (Ljubljana: Modrijan, 2014), 116.

2 Ibid. 
worrisome mass rallies, had yet to take place (in 1987 and especially 1988). The more serious conflicts with Belgrade and Yugoslav People's Army had not happened yet, either. The resounding $57^{\text {th }}$ issue of the Nova revija magazine, containing the contributions to the Slovenian national programme, would not be published until 1987, and the socalled Trial of the Four against Janez Janša and others in front of the Military Court, which mobilised a significant part of the Slovenian community, would not happen for another two years... The public opinion was still quite uncritical and vague at the time. ${ }^{3}$ According to Miran Potrč, the public was focused on the "practical questions", but remained mostly indifferent towards the more general political issues.

Such a social climate was also reflected in the Parliament. Debates about new problematic issues were nonexistent. The proceedings were tedious and very formal, almost bureaucratic, which was the result of the "selfmanagement" system. As it was, Members of the Assembly were not MPs, but rather "delegates" coming from the so-called basic organisations. Therefore, as the delegates were not skilful politicians, they mostly read the "reports" drawn up by their organisations and agreed with the proposals at the sessions. ${ }^{4}$

However, the comfortable life in the Republican Socialist Parliament did not last long: the term from 1986 to 1990 turned out to be turbulent and decisive, and also final incarnation of the "classic" delegate Assembly form. Afterwards the Assembly stopped functioning, but not before singing its swan song. As it happened, in its final years the Assembly was often pushed to the forefront and had a decisive impact on the events.

\section{Republican Socialist Assemblies in the Political System of the Yugoslav Federation}

Before we begin with the in-depth exploration of the activities and character of the Republican Assembly in its final period, we should take a look at the genesis of its creation as well as its position in the Yugoslav political system.

Already during World War II a completely new political system, based on the people's authority, started emerging in the occupied Yugoslavia. In this process Slovenia attained a status of a federal unit (as one of the Yugoslav republics) with its own constitution and statehood. At that time the establishment of a new system under the leadership of the communists took place gradually, in agreement with the Allies, but at the same time resolutely and intensely. While, on one hand, new authorities were being created, on the other hand the former Yugoslav King's government-inexile in London still existed. Therefore both sides sat down at the negotiating table,

3 Jure Gašparič and Mojca Šorn, "Od tovariša delegata do gospoda poslanca: O razpravi v socialistični enostrankarski skupščini in demokratičnem tranzicijskem parlamentu v Sloveniji," Prispevki za novejš zgodovino 54, no. 1 (2014): 37-47.

4 Miran Potrč, interview by author, Ljubljana, April 24, 2014. Sound recordings and transcriptions of the interview are kept by the author. 
especially due to the British pressure, and reached a compromise: on one hand the establishment of a joint government of the resistance movement and governmentin-exile - a kind of a transitional government, which was nothing special in the European context - and on the other hand the "restoration" of multi-party democracy. ${ }^{5}$ At this point we should add that the "restoration" of the multi-party system in Yugoslavia in accordance with the King Alexander Karađorđević Imposed Constitution of 1931 and the accompanying electoral law would imply the introduction of public elections where not everyone could run for office. It would therefore mean the introduction of a kind of multi-party democracy disputable even in its formalistic aspect. ${ }^{6}$ After the war the pre-war multi-party system was in fact not fully restored, but rather only partially. Yet in the formal sense this was even more prudent. As it was, the elections were now secret, minor parties allowed, and in the beginning even media pluralism was acceptable. ${ }^{7}$ However, in all other aspects and conditions for the development of the political life this restoration was largely a replication of the 1930s.

In a state where a multi-party system was not desired, a state-wide coalition named the People's Front was established, headed by the Communist Party. ${ }^{8}$ The socalled extraFront opposition was thwarted (the communists controlled the repressive apparatus and the political police), and therefore the opposition ultimately failed to appear at the elections. A single list, which could count on winning in any case, competed for the votes. ${ }^{9}$ In the autumn of 1945 the American embassy in Yugoslavia reported to Washington that the country was turning into a totalitarian police state with no freedom of speech and press, but that "significant opposition or objections to the existing situation are nevertheless virtually non-existent". ${ }^{10}$

While in certain parts of Yugoslavia, especially in Serbia, the opposition remained active despite the difficulties, the situation in Slovenia was completely different. Here the idea and political form of the People's Front had already been implemented by the communists as early as in 1941, when the Liberation Front was established. At a congress immediately after the war the Liberation Front pronounced itself as the

5 For more information see Jerca Vodušek Starič, Prevzem oblasti (Ljubljana: Cankarjeva založba, 1992), 106-07, 130-45.

6 Jure Gašparič, SLS pod kraljevo diktaturo: Diktatura kralja Aleksandra in politika Slovenske ljudske stranke 1929-1935 (Ljubljana: Modrijan, 2007), 116-24.

7 Aleš Gabrič, “Opozicija v Sloveniji po letu 1945," Prispevki za novejšo zgodovino 45, no. 2 (2005): 104. Vodušek Starič, Prevzem oblasti, 166-67, 331-37.

8 The basic characteristics of the "People's Front" approach was the same throughout the Central and Southeastern Europe. For example, a similar platform was also established in Czechoslovakia, where the non-communist politics headed by Beneš had a far stronger starting position as in Yugoslavia. The socalled "Košice Government Programme", which was the first step towards "people's democracy", was comprehended in various ways at that time. Some people saw in it a maximum package of reforms, while others believed it was merely the beginning of a radical transformation. - Jiří Vykoukal, Bohuslav Litera and Miroslav Tejchman, Východ: Vznik, vývoj a rozpad sovètského bloku 1944-1989 (Praha: Libri, 2000), 126.

9 Vodušek Starič, Prevzem oblasti, 343-69.

10 Gabrič, "Opozicija po 1945," 102. 
"only political representative for the whole of Slovenia". 11 The actual power of the Liberation Front, primarily stemming from the resistance against the occupiers and the victory in the national liberation war, was not questionable either. The political structure of Slovenia after 1945 became increasingly monolithic. However, the complete absence of any opposition did not result exclusively from the activities of the communists, but also from the actions of the pre-war political parties. Their wartime activities and collaborationist heritage had pushed them to the edge of the political space. $^{12}$

After World War II we can therefore no longer speak about classic parliamentarism, since despite the existence of the Assembly and elections only a single political party existed in this period. Apart from the oneparty aspect, the main characteristics of the postwar system also included the constant distancing from the principles of the functioning of the classic parliamentary system and gradual introduction of a specific corporatist system. This was also evident from the structure of each Assembly.

The Constitutional Assembly consisted of two chambers: the Federal Assembly, elected on the basis of the state-wide and equal right, and the National Assembly, where each republic had 25 representatives. Unicameral Assemblies of the People's Republics existed at the republican level. ${ }^{13}$ After the 1953 constitutional reform the National Assembly was annexed to the Federal Assembly, and in its stead a new chamber, called the Council of Producers, was established. Its members were elected indirectly, according to the specific branches of economy, which was the first step towards corporatism. The new constitution of 1963 implemented a further systemic upgrade. The Federal Assembly, later renamed as the Assembly of the Socialist Federal Republic of Yugoslavia, was expanded to five councils (chambers): Federal Council (which included the Council of Nations), Economic Council, Educational and Cultural Council, Social and Health Council, and Organisational-Political Council. The same system was introduced in each of the republics, but here the Republican Council took the place of the Federal Council. ${ }^{14}$

Despite the one-party Assembly system, several elements of classic parliamentarism can be identified in the activities of the Slovenian Assemblies throughout this time. However, these elements were merely fragmentary and especially characteristic of the period of the so-called Party liberalism in the 1960s. Already in 1966 President of the Government Janko Smole tied the question of the government vote of

11 Božo Repe, Rdeča Slovenija: Tokovi in obrazi iz obdobja socializma (Ljubljana: Sophia, 2003), 25.

12 Janko Pleterski, "O soslednosti novejše zgodovine Slovencev: Nekaj pripomb ob in k posvetu Slovenci in leto 1941," Prispevki za novejšo zgodovino 43, no. 1 (2003): 109.

13 Aleš Gabrič, "Volitve v Ustavodajno skupščino novembra 1945," in Slovenska novejša zgodovina: Od programa Zedinjena Slovenija do mednarodnega priznanja Republike Slovenije: 1848-1992, ed. Jasna Fischer et al. (Ljubljana: Inštitut za novejšo zgodovino, Mladinska knjiga, 2005), 854-60. Aleš Gabrič, "Prva slovenska ustava," in Slovenska novejša zgodovina, 867-68.

14 Mateja Režek, "Ustava reforma leta 1953," in Slovenska novejša zgodovina, 950-52. Mateja Režek, "Na pragu reform," in: Slovenska novejša zgodovina, 998-99. 
confidence to the vote on a concrete proposal, which was completely unusual for the Assembly system (unlike the parliamentary system); while the classic role of MPs became especially apparent a few years later. In 1971 an actual political affair broke out, known as the "Affair of 25 Deputies". At this time a group of deputies proposed, apart from the "official" candidate, its own candidate as a member of the Presidency of the Socialist Federal Republic of Yugoslavia. Although unsuccessful, this action questioned the monopoly of personnel management of the Party leadership. ${ }^{15}$

\section{The "Delegate System" (1974-1991)}

The last thorough constitutional reform followed in 1974 (before that numerous constitutional amendments had been adopted between 1968 and 1971). This reform represented the peak of the "Yugoslav experiment" and remained in force until the 1990s. A system of delegates was introduced, which was a nontransparent and impractical indirect concept of total selfmanagement. The Federal Assembly of the Socialist Federal Republic of Yugoslavia once again became bicameral, consisting of two equal chambers: the Federal Chamber and the Chamber of Republics and Provinces, to which the delegates were appointed from the Assemblies of six republics and two autonomous provinces. The Republican Assemblies, also the Slovenian Assembly, became tricameral, consisting of the Chamber of Associated Labour, Chamber of Municipalities and SocioPolitical Chamber. ${ }^{16}$

The delegate system, outlined primarily by the Slovenian politician Edvard Kardelj and his supporters, was, according to Peter Vodopivec, based on the author's "Bolshevik Proudhonistic sociopolitical fantasies" (one of the reasons why in the West Kardelj was mockingly referred to as an "ideological tailor"). The architects of the new order deconstructed the whole society together with all organisations into the smallest possible parts (all institutes, institutions, companies, etc.), which would supposedly encourage the mass politicisation of the population and their engagement. In the second half of the 1970s almost 300,000 people - in Slovenia with its two million inhabitants - were included into the delegate functions. ${ }^{17}$

How could a citizen become a delegate in the Slovenian Assembly? If it was a question of the Chamber of Municipalities, a citizen had to be first elected as a member of the "basic" delegation, for example in his/her local community. Then the local communities elected delegations for the municipal communities, and after that

15 Ciril Ribičič, Siva tipka 074 (Ljubljana: Enotnost, 1995), 17-24.

16 Zdenko Čepič, "Federaliziranje federacije 1967-1971," in Slovenska novejša zgodovina, 1052-54. Zdenko Čepičc, "Ustava 1974: preureditev jugoslovanske federacije, delegatski sistem in dogovorna ekonomija," in Slovenska novejša zgodovina, 1094-101. Božo Repe, "Pravne in politične podlage, okoliščine in pomen prvih demokratičnih volitev," in: Razvoj slovenskega parlamentarizma: Kolokvij ob 10. obletnici parlamentarizma v Sloveniji: Zbornik referatov, koreferatov in razprav, ed. Tatjana Krašovec (Ljubljana: Državni zbor Republike Slovenije, 2000), 41-62.

17 Peter Vodopivec, "Komunistične skupščine v senci partije," in: Analiza razvoja slovenskega parlamentarizma, ed. Barbara Vogrinec (Ljubljana: Inštitut za civilizacijo in kulturo, 2005), 286-87. 
the municipal communities organised the groups of delegates to join the Republican Assembly. On each occasion one of the delegates from the group attended the session of the Republican Parliament, chosen on the basis of the issues on the agenda. ${ }^{18}$ If it was a question of the Chamber of Associated Labour, a citizen had to be first elected as a member of the delegation in his/her company (factory). These delegations sent delegates to the Municipal Chamber of Associated Labour, which at the end chose the delegates for the Republican Assembly. If it was a question of the Socio-Political Chamber, a citizen had to be a member of a "socio-political organisation" and as such elected as a member of the Republican Assembly by the municipal socio-political chambers. ${ }^{19}$

What this meant for the status of the delegates was described vividly by the literary historian Dušan Pirjevec: "To be a Member of Parliament nevertheless meant something once. Today it means nothing to be a delegate. This is no longer a political function - the only politicians left are members of the Party." ${ }^{20}$ Miha Ribarič, secretary of the constitutional commission of the Republican Assembly, said something similar already in 1978: "One of the fundamental unacceptable characteristics of the delegate Assembly system is ... that the delegate Assemblies in fact often function as a sort of ratification or verification bodies of materials, decisions, solutions and proposals, prepared by the executive or administrative bodies." 21

However, the Yugoslav crisis intensified and a decade after Ribaričs resigned observations the role of Assemblies and delegates started changing. The sessions of the Federal Assembly became increasingly lively and conflicting, and it even happened that in 1988 the President of the Federal Government Branko Mikulić resigned because he failed to secure the Assembly support for his budget proposal. ${ }^{22}$ While this is a rather normal occurrence in classic parliamentary democracies, in Yugoslavia this happened for the first time after 1945. However, at that time certain Republican Assemblies started becoming far more important than the Federal Parliament, among them especially the Slovenian Assembly.

18 See Zakon o volitvah in delegiranju v skupšcine: Zakon o volitvah in odpoklicu Predsedstva Socialistične republike Slovenije s pojasnili Cirila Ribičiča in Franca Grada (Ljubljana: ČZ Uradni list SRS, 1985).

19 Apart from these chambers, the "Self-Management Interest Associations" were a part of the assembly system at the time as well (SIS). These "associations" supposedly enabled people to express their common interests in the fields of education, culture, health. Special assemblies of Self-Management Interest Associations made decisions about matters from their jurisdiction on equal footing with the competent Assembly chambers.

20 Vodopivec, "Komunistične skupščine v senci partije," 287.

21 Miha Ribarič, Spomini: Slovenija - Jugoslavija (Ljubljana: Fakulteta za družbene vede, 2015), 61.

22 Vodopivec, "Komunistične skupščine v senci partije," 292. 


\section{The Final Convening of the Slovenian Socialist Assembly and Its Place in Historiography}

The crisis, which went on unacknowledged by the Yugoslav political elites for a long time (the leading politicians avoided the term "crisis" consciously), and all its many layers, economic as well as social and political, had an increasingly obvious impact on that period. The numerous solutions that were gradually outlined were very diverse and exceedingly dependent on the individual republican elites. Due to the federal structure of the state this led to severe mutual conflicts. The elite that gathered around Slobodan Milošević (initially the President of the Central Committee of the League of Communists of Serbia, then the President of Presidency of the Socialist Republic of Serbia) asserted itself as the strongest and also most aggressive. Together with its allies (the Montenegrin, Kosovo and Vojvodina leadership) it argued for the increased powers of the central federal authorities, therefore for the reduction of federalism and for the classic socialist system that Yugoslavia had adhered to before the constitutional reforms between 1971 and 1974. On the other hand a tentative alliance formed between Slovenia, Croatia, Bosnia and Herzegovina and Macedonia, brought together especially because of the fear of the centralist and nationalist offensive of the Milošević's circle. Within this circle the leadership of the League of Communists of Slovenia argued for the clearest standpoints, aimed at the democratisation of the society, allowing the formation of noncommunist political groups, a more prominent role of the republics and market economy. ${ }^{23}$

The already loose federal system kept getting looser and the political control in the individual republics was becoming less and less effective. The demands for pluralism and systemic changes became increasingly decisive, and finally they also manifested themselves in the hall of the Slovenian Assembly of delegates. Thus in its final convening between 1986 and 1990, the Slovenian Assembly became one of the key supporters of a peaceful and evolutionary transformation into a multiparty parliamentary system. The adoption of numerous constitutional amendments to the Slovenian Constitution in September 1989 was especially important. ${ }^{24}$

In the increasingly tense circumstances at the time, on 27 September 1989 the delegates, with the strong engagement of the civil society, ${ }^{25}$ actually introduced an asymmetrical position of Slovenia in the federation, as they implemented the "security, economic and developmental priority of interests and needs of Slovenia" before the federation. Furthermore, they enabled the conditions for direct and secret

23 Božo Repe, Jutri je nov dan: Slovenci in razpad Jugoslavije (Ljubljana: Modrijan, 2002), 63-73, 232-35.

24 Miran Potrč, "Za prvo demokratično izvoljeno Skupščino Republike Slovenije je dala zakonsko podlago zakonodaja, sprejeta 27. 12. 1989 v Skupščini Socialistične Republike Slovenije," in Prihodnost parlamentarne demokracije: Zbornik strokovnega srečanja ob 20. obletnici prvih večstrankarskih volitev, ed. Tatjana Krašovec and Mojca Pristavec Đogić (Ljubljana: Državni zbor Republike Slovenije, 2010), 26-32.

25 For more information about the circumstances see Repe, Jutri je nov dan, 177-83. 
elections, ${ }^{26}$ allowed for the establishment of political parties, and introduced elements of market economy. ${ }^{27}$ Throughout this process important political debates unfolded in the Assembly and farreaching decisions were made. Even symbolism always an important matter in politics - was not lacking. In September 1989, after adopting the constitutional amendments, the delegates spontaneously (and allegedly quite out of tune) sang Zdravljica (A Toast), the song that one of the amendments proclaimed as the Slovenian anthem. Zdravljica was written in 1847 by the most important poet of the Slovenian romantic period France Prešeren, famous among the people and almost synonymous with Slovenian literature. Everybody knew the popular song (structurally a toast), and they declared their adherence by singing it. Many a tear was shed on this occasion, and the Assembly politics was no longer boring, but rather very emotional...

Thus it seems, at the first glance, that in 1989 the Assembly became the primary factor of the transition: as it was, it adopted the acts that shook the Yugoslav federation. However, such assessments cannot be found in the historiographic literature. The authors who focus on the dissolution of Yugoslavia and definitely mention the adoption of the constitutional amendments rarely look carefully at the authority body that adopted them and the way in which they were adopted. ${ }^{28}$ They usually refer to the voting in the Assembly with expressions like "Slovenia adopted" or "Slovenians decided" or "Slovenian politics opted for", etc. On this basis we can make at least two different conclusions about the character of the Assembly at the time:

- either that in the opinion of numerous experts in Yugoslavia until 1990 decisions were still made by a few people in the key positions, while the Assembly merely verified their decisions, which merely happened to be resounding and very significant in 1989;

- or that despite the delegate system the Assembly was a body of representatives

26 The elections were called for April 1990. Apart from a few former sociopolitical organisations, transformed into political parties, new parties united in the Demos coalition also competed for the votes. Altogether this coalition received the majority of the votes and formed a government. The political life proceeded increasingly in the spirit of multiparty parliamentarism, although "only" the delegate Assembly, consisting of three chambers, existed.

27 Potrč, Klic k razumu: spomini, 127-40.

28 See for example Robert M. Hayden, Blueprints for a House Divided: The Constitutional Logic of the Yugoslav Conflicts (Ann Arbor: The University of Michigan Press, 2000). Susan L. Woodward, Balkan Tragedy: Chaos and Dissolution after the Cold War (Washington D. C.: The Brookings Institution, 1995). Sabrina P. Ramet, The Three Yugoslavias: State-Building and legitimation, 1918-2005 (Washington D. C.: Woodrow Wilson Center Press, 2005). Lenard J. Cohen, Broken Bonds: The Disintegration of Yugoslavia (Boulder, San Francisco, Oxford: Westview press, 1993). There is a noticeable difference between the way in which the Assembly is seen by Slovenian and foreign authors. Slovenian authors generally pay more attention to it and try to explain its decisions; primarily Repe, Jutri je nov dan and the authors of the work Slovenska novejša zgodovina, apart from them also Stefano Lusa, Razkroj oblasti: Slovenski komunisti in demokratizacija države (Ljubljana: Modrijan, 2012). Rosvita Pesek, Osamosvojitev Slovenije: "Ali naj Republika Slovenija postane samostojna in neodvisna država?" (Ljubljana: Nova revija, 2007). The Assembly is seen in a similar manner also by Viktor Maier, Wie Jugoslawien verspielt wurde (München: C. H. Beck, 1995). 
which embodied the political will of the population of the Socialist Republic of Slovenia.

The role of the Assembly is thus unclear, and the logical question is therefore the following:

\section{What Sort of an Authority Body Was the Socialist Assembly?}

In the Yugoslav federation, the Slovenian Socialist Assembly at this time, as the socialist system was falling apart, was a rather complicated organism, and it should be analysed in detail. In order to ensure its understanding and temporal placement I will attempt to deal with three levels: the formalistic legal level, the perceptual level, and the manner in which the Assembly operated.

\section{Legal level}

In view of the legal sources (especially the 1974 Constitution) and literature we can state almost definitely that during the dissolution of the state the Assembly was an authority body impossible to bypass. "The Assembly of the Socialist Republic of Slovenia is a social self-management body and the highest authority in the framework of the rights and duties of the republic", stated Article 334 of the republican constitution. ${ }^{29}$ As such it was an important factor in the process of political decisionmaking with broad jurisdictions. ${ }^{30}$ There was nothing else - not at the federal nor at the republican level - that could replace it. The decision-making process at the time was "implemented through complicated mechanisms and procedures", which often only formally ensured the democratic choice and participation of the people. In fact the purpose of the self-management mechanisms, according to Miran Potrč, was primarily to ensure that the system as envisioned in the Party programmes was not threatened. ${ }^{31}$ However, without the Assembly the adoption of decisions was nevertheless impossible, especially when it came to amending the constitution. In his commentary on the adoption of the constitutional amendments, the constitutional lawyer Miha Ribarič wrote that with these amendments Slovenia addressed some of the key questions regarding its position in Yugoslavia - a federation which in itself had "no original functions and jurisdictions; meaning such that would not originate from its members." 32 The members of the federation, the republics, could therefore strengthen or weaken their own position through the decisions adopted in their Assemblies. Furthermore, in 1989 many people in Belgrade found it questionable whether the decisions of the Slovenian Assembly, which strengthened the Slovenian position, were compatible with the Constitution of the Socialist Federal Republic of

29 Ustava Socialistične republike Slovenije, $\$ 334$.

30 Ustava Socialistične republike Slovenije, $\$ 335$.

31 Potrč, Klic k razumu: spomini, 121.

32 Ribarič, Spomini: Slovenija - Jugoslavija, 230-34. 
Yugoslavia. However, no one questioned the formal manner in which these amendments were adopted.

Thus the Assembly had all of the systemic conditions for actually carrying out an important political role in the system. Without its engagement the political changes would not be possible, at least not in the constitutional manner characteristic of the Slovenian emancipation process and the initial stage of its political transition. After all, even the current Slovenian Constitution from 1991 was adopted in accordance with the constitutional revision procedures, set out in the preceding 1974 Constitution. ${ }^{33}$

At the same time the Assembly was an elected authority body, even if in a special delegate manner. The delegation elections differed significantly from the classic parliamentary elections, as they did not reflect the "single act of the voters, authorising the elected Members of Parliament to adopt governmental decisions as their general representatives and in their name". According to the legal interpretation at the time, the delegation elections meant "the beginning of a permanent, four-year working cooperation between delegations and delegates, working people and citizens..." Supposedly people were "continuously deciding" which guidelines their delegates should observe. The system was a kind of an implementation of direct democracy. Consequently the Assembly was not envisioned as a classic representative body. ${ }^{34}$

\section{Perceptual level / perception of the Assembly}

The second moment, important in order to understand the role and activities of the Assembly, is its perception among the people, the trust in the Assembly and vice versa: the Assembly's interaction with the public opinion, with the impulses of the time as felt by the population. Miran Potrč says:

"I am convinced it is very likely that the connection between the public opinion, the demands of the civil and social organisations as they were established at the time... that the links between them and the Parliament were stronger than today. ... These connections were stronger then... For example in 1990, or between 1986 and 1990, between 1988 and 1990. Much stronger. At that time we paid great attention to the public opinion. We were very mindful of what was discussed in public, what the public demands were. I am not saying that we satisfied all of them, far from it, but we considered more or less all of these demands and met them in many ways. "35

We should also emphasise that at that time the delegates were not the same people for the whole term: due to the system of interchangeable delegates the Assembly

33 Jure Gašparič, Državni zbor Republike Slovenije 1992-2012: O slovenskem parlamentarizmu (Ljubljana: Inštitut za novejšo zgodovino, 2012), 42-46.

34 Zakon o volitvah in delegiranju v skupšcine: Zakon o volitvah in odpoklicu Predsedstva Socialistične republike Slovenije s pojasnili Cirila Ribičiča in Franca Grada, uvodna pojasnila.

35 Miran Potrč, interview by author, Ljubljana, April 24, 2014. 
sessions could be attended by new, different delegates, sometimes also sympathisers of the new social movements. ${ }^{36}$

Thus the Assembly could follow the wishes and observe the demands of the public, and the delegates were aware of their responsibility. For example, when President of the Assembly Potrč opened the session on the occasion when the amendments were adopted, he said: "It has been a long time since the delegates of this Assembly had such a profound responsibility to the Slovenian nation as we do today." 37

However, did the public share the opinion that this was the case? Did the people see the Assembly as their representative?

The results of the public opinion polls at the time are very revealing. In 1986, as far as the municipal level was concerned, $50 \%$ of people answered "yes" to the question: "We have just held the Assembly election. Do you feel that you have taken part in the selection and appointment of the candidates for the leading functions?". However, when their participation in the appointment of the leading candidates at the republican and federal level was in question, almost three quarters of interviewees answered "no". ${ }^{38}$ People obviously felt that the delegate system was alienated and they felt that they did not take part in the formation of the Assembly.

Neither were they very familiar with the political system: in 1989, on the eve of the adoption of the constitutional amendments, most of them were unable to name all three Assembly Chambers.

However, on the other hand the answers of the people were in favour of the Assembly. A minimal percentage responded that they did not trust the Assembly. Mostly they only wished for more (direct) democracy (which is a sort of a paradox, as this very system supposedly implemented direct democracy). It was especially important that at the time a very large majority of people agreed with the constitutional amendments. 39

The favourable inclination that the people showed to the decisions of the Assembly on the day when the amendments were adopted and immediately after that day reached dimensions which are rare even in the system of the classic parliamentary democracy. When the delegates arrived to the Assembly, the representatives of a new social movement (which later grew into a political party, like many others) the Greens of Slovenia distributed apples for encouragement; and when the delegates were leaving, a crowd of people waited for them, applauding. The passing cars

36 Zakon o volitvah in delegiranju v skupšcine: Zakon o volitvah in odpoklicu Predsedstva Socialistične republike Slovenije s pojasnili Cirila Ribičiča in Franca Grada. Potrč, Klic k razumu: spomini, 117.

37 “Slovenska ustava stremi k svobodi in kreativnosti ljudi," Delo, September 28, 1989.

38 Niko Toš et al., Slovensko javno mnenje 1986 [database] (Ljubljana: Univerza Edvarda Kardelja, Fakulteta za sociologijo, politične vede in novinarstvo, Center za raziskovanje javnega mnenja in množičnih komunikacij [creation ], 1986; Ljubljana: Univerza v Ljubljani, Fakulteta za družbene vede, Arhiv družboslovnih podatkov [distribution ], 1999).

39 Niko Toš et al., Slovensko javno mnenje 1989: Stališča o ustavnih dopolnilih [database] (Ljubljana: Univerza Edvarda Kardelja, Fakulteta za sociologijo, politične vede in novinarstvo, Center za raziskovanje javnega mnenja in množičnih komunikacij [creation ], 1989; Ljubljana: Univerza v Ljubljani, Fakulteta za družbene vede, Arhiv družboslovnih podatkov [distribution ], 1999). 
honked their horns euphorically. It is also not negligible that the Slovenian delegates were under significant pressure throughout this time. Almost all federal bodies were opposed to the adoption of the amendments. The discussions about them were frequently turbulent and very emotional, the warnings foreboding, and in the end the Slovenian Assembly was "more or less explicitly" advised to postpone the adoption of the amendments. In his commentary after the adoption of the amendments, the journalist of the central Slovenian daily newspaper Delo, Danilo Slivnik, wrote:

"In the following days some people will try to add to or subtract from this event, typical of politics everywhere. However, they will hardly be able to change the fact that the current political turning point in Slovenia is a consequence of wider democratic changes in the republic, in which everyone from the still incomplete national political circle participated: from those individuals who kept sending their "letters to the editor" to various newspapers for months and months... To the representatives of the most "official politics". 40

Thus in September 1989 the Assembly was implementing the political will of the population. However, as the young Slavko Gaber, later a long-time Minister of Education, underlined in a newspaper column: the Assembly could only acquire this legitimacy by "taking steps towards the normal conclusion of its term". He claimed that the Assembly could not take merit as a classic elected Parliament, therefore he spoke in favour of its abolishment. ${ }^{41}$ This in fact happened shortly afterwards, but the dilemma remained: was the Assembly only legitimate because with its own decisions it simultaneously abolished itself?

\section{Operating principle}

In order to understand the last, $10^{\text {th }}$ convening of the Slovenian Socialist Assembly, I believed that it was necessary to ask another question: in what way did the Assembly operate, had its cultural pattern changed, had the internal mechanisms during the sessions been altered? In order to find the answer I employed a different methodological approach, making use of the advances of digital humanities. Building on the thesis that every parliament (even the socialist kind) primarily focuses on and pays attention to discussions, I have analysed the quantitative characteristics of discussions on the basis of a few reference books containing verbatim records of the Assembly sessions. Thus my colleague Andrej Pančur and I have checked how many words the delegates (and later MPs) spoke at individual sessions, how many different speeches they held, how many words they used for discussing an individual item, and what was the proportion between the number of words of the President and the other participants of the discussions. The results are not very surprising, even if they may initially appear to be.

40 Danilo Slivnik, "Po meri Slovencev," Delo, September 28, 1989.

41 Slavko Gaber, "Skupščina komunistov se odpravi," Telex, October 26, 1989. 
Table 1: A part of the quantitative analysis, prepared by Andrej Pančur on the basis of selected collections of verbatim records of certain Assembly I Parliament sessions in the stated years

\begin{tabular}{|c|c|c|c|c|c|}
\hline Year & $\begin{array}{c}\text { Number of } \\
\text { speeches per } \\
\text { session }\end{array}$ & $\begin{array}{c}\text { Number of } \\
\text { words per } \\
\text { session }\end{array}$ & $\begin{array}{c}\text { Number of speeches } \\
\text { of the President per } \\
\text { session }\end{array}$ & $\begin{array}{c}\text { Number of words } \\
\text { of the President } \\
\text { per session }\end{array}$ & $\begin{array}{c}\text { Proportion: words } \\
\text { of the President vs. } \\
\text { everyone else }\end{array}$ \\
\hline 1973 & 73 & 16315 & 42 & 3524 & 0.22 \\
\hline 1982 & 71 & 18987 & 42 & 5497 & 0.29 \\
\hline 1984 & 90 & 27252 & 53 & 7088 & 0.26 \\
\hline 1986 & 98 & 22055 & 59 & 6909 & 0.31 \\
\hline 1987 & 111 & 25123 & 63 & 7190 & 0.29 \\
\hline 1989 & 130 & 35530 & 75 & 10045 & 0.28 \\
\hline 1990 & 472 & 68401 & 221 & 18610 & 0.27 \\
\hline 1991 & 258 & 54498 & 133 & 12627 & 0.23 \\
\hline 1992 & 415 & 76544 & 225 & 26218 & 0.34 \\
\hline
\end{tabular}

\begin{tabular}{|c|c|c|}
\hline Year & $\begin{array}{c}\text { Number of words per } \\
\text { session item }\end{array}$ & $\begin{array}{c}\text { Proportion: words of the President } \\
\text { vs. everyone else per item }\end{array}$ \\
\hline 1973 & 1991 & 0.19 \\
\hline 1982 & 1386 & 0.27 \\
\hline 1984 & 1830 & 0.22 \\
\hline 1986 & 1396 & 0.27 \\
\hline 1987 & 1057 & 0.25 \\
\hline 1989 & 1978 & 0.25 \\
\hline 1990 & 1904 & 0.22 \\
\hline 1991 & 3761 & 0.21 \\
\hline 1992 & 2557 & 0.31 \\
\hline
\end{tabular}

Since the 1980s the number of speeches at individual sessions was rising steadily, but then increased radically in 1990 (dissolution of the state) and 1992 (swift adoption of new legislation). Simultaneously the number of words spoken at individual sessions was increasing as well, especially after 1989. The Presidents spoke more often and longer. Even the number of words, spoken during the discussion of individual items, increased. (Thus the proportion between the number of words spoken at a single session and the number of words spoken by the President remained relatively static.)

It seems that the political dynamics, felt all around Slovenia and Yugoslavia, also found its way into the Assembly and characterised its work: more was said there. On the basis of certain case studies we may also conclude that gradually not only more was said, but also differently: the language started changing and the reading 
of "reports" became rarer, while political passion intensified. ${ }^{42}$ The upgrading of the search tools in the context of the digitalisation of session records, currently carried out at the Institute of Contemporary History, will allow for a more advanced and temporally more comprehensive linguistic research, not only regarding the quantitative characteristics, but also the contents of what was said. The stated information is only partial, therefore its representativeness is questionable.

\section{Conclusion}

We can establish that the socialist Parliament on the eve of the dissolution of Yugoslavia has not yet been explored in much detail. This is true in case of the republican Assemblies as well as the Federal Assembly in Belgrade. However - at least we can claim this for Slovenia - at this time the Assembly underwent internal changes and, most notably, started adopting important decisions: in the process of the dissolution of Yugoslav federalism it was a constitutional and political factor which could not be ignored.

We can partially agree that the Assembly (also) gained legitimacy by steadily marching towards its end, although in this regard we should also add that the legitimacy of the Assembly and trust in it by the people was encouraged at least in the same degree (if not more so) by the threat that the people saw in Belgrade. In 1989 the answers to the public opinion poll question "In the current circumstances, what represents the greatest threat to the sovereignty of Slovenia?" included especially the following three issues:

- that "we have excessive economic responsibilities to the federation and the underdeveloped";

- that "the federal authorities are authoritarian in their rejection of important Slovenian proposals";

- and that "Slovenian political pluralism and democratisation was under attack outside of Slovenia".

Therefore the Slovenian Assembly represented defence from the Belgrade threat. This was reason enough why it was seen as a legitimate representative body, a parliament with a purpose.

The federal institutions, including the League of Communists of Yugoslavia, were different: they were becoming an end in themselves. Paradoxically, these institutions were able to persist precisely because of the Slovenian Assembly and similar authority bodies, as the League of Communists of Yugoslavia as well as other federal institutions justified their own existence at least partially by responding to the decisions of the Slovenian Assembly. In September 1989, during the adoption of the Slovenian constitutional amendments, a motto wittily and evidently illustrating the logic of the Party sessions became popular: "If you have problems, convene a session of the

42 Gašparič and Šorn, "Od tovariša delegata do gospoda poslanca," 37-47. 
Central Committee. This will result in even more problems, but at least you'll have a Central Committee session." 43

The legitimacy of the federal authorities gradually disappeared completely, and only a few Western countries saw the Federal Assembly and the federal government of the reformist prime minister Ante Marković as a credible party.

In the meantime the credibility of the Slovenian Assembly kept strengthening, especially after April 1990 when the first multi-party elections by secret ballot were carried out for the first time after 1927. At that time the Assembly was filled with delegates who, despite the existing constitution, called themselves Members of Parliament, which was more appropriate for the new times. The largest number of MPs came from new parties, but we should note that the former League of Communists of Slovenia and the other former "socio-political organisations" had a very good result as well. The latter can perhaps be interpreted as an additional argument supporting the thesis that in the final period the former Socialist Assembly was nevertheless a legitimate "representative" institution, supported by the population. Finally, in 1991 people in Slovenia believed that democracy in their republic was not very different from the democracies in the Western European countries. They were probably wrong, but still - they (at least partially) based this opinion on their experience with their socialist Parliament, which was, comparatively speaking, the most positive in the whole of Eastern Europe. ${ }^{44}$

\section{Table 2: Consolidation of democracy in Central and Eastern Europe, 1991 / 1999}

\begin{tabular}{|l|c|c|c|c|}
\hline Country & Year & $\begin{array}{c}\text { Our State should } \\
\text { develop like } \\
\text { Western European } \\
\text { Countries }\end{array}$ & $\begin{array}{c}\text { In our State will } \\
\text { never be possible to } \\
\text { implement the true } \\
\text { Democracy }\end{array}$ & $\begin{array}{c}\text { Democracy in our State } \\
\text { is similar to democracies } \\
\text { in Western European } \\
\text { countries }\end{array}$ \\
\hline White Russia & 1999 & 62.9 & 29.3 & 2.8 \\
\hline Bolgaria & 1991 & 81.2 & 17.9 & 6.2 \\
\cline { 2 - 5 } & 1999 & 76.7 & 48.2 & 92.1 \\
\hline Czech Republic & 1991 & 77.2 & 13.1 & 13.4 \\
\cline { 2 - 5 } & 1999 & 76.0 & 30.0 & 16.3 \\
\hline Estonia & 1991 & 73.5 & 16.4 & 6.4 \\
\cline { 2 - 6 } & 1999 & 69.3 & 18.1 & 28.2 \\
\hline East Germany & 1991 & 80.2 & 21.4 & 30.2 \\
\cline { 2 - 6 } & 1999 & 82.8 & 21.5 & 64.7 \\
\hline West Germany & 1999 & 86.9 & 18.7 & \\
\hline
\end{tabular}

43 Rastko Močnik, "Paralogizmi argumentov in logika institucije," Telex, October 5, 1989.

44 Vrednote v prehodu VIII: Slovenija v srednje in vzhodnoevropskih primerjavah, ed. Niko Toš (Ljubljana: Univerza v Ljubljani, Fakulteta za družbene vede, IDV - CJMMK; Wien: Edition Echoraum, 2014), 334 . 


\begin{tabular}{|l|c|c|c|c|}
\hline \multirow{2}{*}{ Hungary } & 1991 & 94.8 & 20.7 & 7.6 \\
\cline { 2 - 5 } & 1999 & 94.2 & 23.5 & 16.9 \\
\hline Latvia & 1999 & 58.5 & 14.9 & 8.5 \\
\hline \multirow{3}{*}{ Lithuania } & 1991 & 86.2 & 20.7 & 10.7 \\
\cline { 2 - 5 } & 1999 & 81.2 & 24.5 & 15.1 \\
\hline \multirow{3}{*}{ Poland } & 1991 & 97.1 & 31.3 & 16.5 \\
\cline { 2 - 5 } & 1999 & 92.9 & 46.3 & 24.6 \\
\hline Romania & 1991 & 93.9 & 23.5 & 18.1 \\
\cline { 2 - 5 } & 1999 & 95.4 & 22.8 & 24.3 \\
\hline Russia & 1999 & 34.0 & 35.6 & 10.0 \\
\hline Slovakia & 1991 & 67.2 & 15.8 & 12.2 \\
\cline { 2 - 5 } & 1999 & 73.5 & 40.3 & 10.8 \\
\hline Slovenia & 1991 & 96.9 & 17.2 & 41.1 \\
\cline { 2 - 5 } & 1999 & 89.4 & 18.5 & 75.5 \\
\hline Ukraine & 1991 & 74.1 & 35.1 & 3.9 \\
\cline { 2 - 5 } & 1999 & 66.1 & 44.7 & N \\
\hline
\end{tabular}

Source: Vrednote v prehodu VIII: Slovenija v srednje in vzhodnoevropskih primerjavah, ed. Niko Toš (Ljubljana: Univerza v Ljubljani, Fakulteta za družbene vede, IDV - CJMMK; Wien: Edition Echoraum, 2014), 334.

\section{Sources and Literature}

Literature:

- Čepič, Zdenko. "Federaliziranje federacije 1967-1971.” In Slovenska novejša zgodovina: Od programa Zedinjena Slovenija do mednarodnega priznanja Republike Slovenije: 1848-1992, edited by Jasna Fischer et al., 1052-54. Ljubljana: Inštitut za novejšo zgodovino, Mladinska knjiga, 2005.

- Čepič, Zdenko. "Ustava 1974: preureditev jugoslovanske federacije, delegatski sistem in dogovorna ekonomija." In Slovenska novejša zgodovina: Od programa Zedinjena Slovenija do mednarodnega priznanja Republike Slovenije: 1848-1992, edited by Jasna Fischer et al., 1094-104. Ljubljana: Inštitut za novejšo zgodovino, Mladinska knjiga, 2005.

- Cohen, Lenard J. Broken Bonds: The Disintegration of Yugoslavia. Boulder, San Francisco, Oxford: Westview Press, 1993.

- Gabrič, Aleš. “Opozicija v Sloveniji po letu 1945.” Prispevki za novejšo zgodovino 45, no. 2 (2005): 97-120.

- Gabrič, Aleš. "Prva slovenska ustava." In Slovenska novejša zgodovina: Od programa Zedinjena Slovenija do mednarodnega priznanja Republike Slovenije: 1848-1992, edited by Jasna Fischer et al., 867-68. Ljubljana: Inštitut za novejšo zgodovino, Mladinska knjiga, 2005.

- Gabrič, Aleš. "Volitve v Ustavodajno skupščino novembra 1945." In Slovenska novejša zgodovina: Od programa Zedinjena Slovenija do mednarodnega priznanja Republike Slovenije: 1848-1992, edited by Jasna Fischer et al., 854-58. Ljubljana: Inštitut za novejšo zgodovino, Mladinska knjiga, 2005.

- Gašparič, Jure and Mojca Šorn. "Od tovariša delegata do gospoda poslanca: O razpravi v socialistični enostrankarski skupščini in demokratičnem tranzicijskem parlamentu v Sloveniji." Prispevki za novejš zgodovino 54, no. 1 (2014): 37-47.

- Gašparič, Jure. Državni zbor Republike Slovenije 1992-2012: O slovenskem parlamentarizmu. Ljubljana: Inštitut za novejšo zgodovino, 2012.

- Gašparič, Jure. SLS pod kraljevo diktaturo: Diktatura kralja Aleksandra in politika Slovenske ljudske stranke 1929-1935. Ljubljana: Modrijan, 2007. 
- Hayden, Robert M. Blueprints for a House Divided: The Constitutional Logic of the Yugoslav Conflicts. Ann Arbor: The University of Michigan Press, 2000.

- Lusa, Stefano. Razkroj oblasti: Slovenski komunisti in demokratizacija države. Ljubljana: Modrijan, 2012.

- Maier, Viktor. Wie Jugoslawien verspielt wurde. München: C. H. Beck, 1995.

- Pesek, Rosvita. Osamosvojitev Slovenije: "Ali naj Republika Slovenija postane samostojna in neodvisna država?." Ljubljana: Nova revija, 2007.

- Pleterski, Janko. "O soslednosti novejše zgodovine Slovencev: Nekaj pripomb ob in k posvetu Slovenci in leto 1941." Prispevki za novejšo zgodovino 43, no. 1 (2003): 103-24.

- Potrč, Miran. "Za prvo demokratično izvoljeno Skupščino Republike Slovenije je dala zakonsko podlago zakonodaja, sprejeta 27. 12. 1989 v Skupščini Socialistične Republike Slovenije.” In Prihodnost parlamentarne demokracije: Zbornik strokovnega srečanja ob 20. obletnici prvih večstrankarskih volitev, edited by Tatjana Krašovec, and Mojca Pristavec Đogić, 26-32. Ljubljana: Državni zbor Republike Slovenije, 2010.

- Potrč, Miran. Klic k razumu: spomini. Ljubljana: Modrijan, 2014.

- Ramet, Sabrina P. The Three Yugoslavias: State-Building and legitimation, 1918-2005. Washington D. C.: Woodrow Wilson Center Press, 2005.

- Repe, Božo. "Pravne in politične podlage, okoliščine in pomen prvih demokratičnih volitev." In Razvoj slovenskega parlamentarizma: Kolokvij ob 10. obletnici parlamentarizma v Sloveniji: Zbornik referatov, koreferatov in razprav, edited by Tatjana Krašovec, 26-69. Ljubljana: Državni zbor Republike Slovenije, 2000.

- Repe, Božo. Jutri je nov dan: Slovenci in razpad Jugoslavije. Ljubljana: Modrijan, 2002.

- Repe, Božo. Rdeča Slovenija: Tokovi in obrazi iz obdobja socializma. Ljubljana: Sophia, 2003.

- Režek, Mateja. "Na pragu reform." In Slovenska novejša zgodovina: Od programa Zedinjena Slovenija do mednarodnega priznanja Republike Slovenije: 1848-1992, edited by Jasna Fischer et al., 998-99. Ljubljana: Inštitut za novejšo zgodovino, Mladinska knjiga, 2005.

- Režek, Mateja. “Ustava reforma leta 1953.” In Slovenska novejša zgodovina: Od programa Zedinjena Slovenija do mednarodnega priznanja Republike Slovenije: 1848-1992, edited by Jasna Fischer et al., 950-52. Ljubljana: Inštitut za novejšo zgodovino, Mladinska knjiga, 2005.

- Ribarič, Miha. Spomini: Slovenija - Jugoslavija. Ljubljana: Fakulteta za družbene vede, 2015.

- Ribičič, Ciril. Siva tipka 074. Ljubljana: Enotnost, 1995.

- Vodopivec, Peter. "Komunistične skupščine v senci partije." In Analiza razvoja slovenskega parlamentarizma, edited by Barbara Vogrinec, 258-97. Ljubljana: Inštitut za civilizacijo in kulturo, 2005.

- Vodušek Starič, Jerca. Prevzem oblasti. Ljubljana: Cankarjeva založba, 1992.

- Woodward, Susan L. Balkan Tragedy: Chaos and Dissolution after the Cold War. Washington D. C.: The Brookings Institution, 1995.

- Vykoukal, Jiř́, Bohuslav Litera, and Miroslav Tejchman. Východ: Vznik, vývoj a rozpad sovétského bloku 1944-1989. Praha: Libri, 2000.

\section{Newspaper sources:}

- Delo. "Slovenska ustava stremi k svobodi in kreativnosti ljudi." September 28, 1989.

- Gaber, Slavko. "Skupščina komunistov se odpravi." Telex, October 26, 1989.

- Močnik, Rastko. "Paralogizmi argumentov in logika institucije." Telex, October 5, 1989.

- Slivnik, Danilo. "Po meri Slovencev." Delo, September 28, 1989.

Oral, legal, database sources:

- Potrč, Miran. Interview by author. Ljubljana: April 24, 2014. Sound recordings and transcriptions of the interview are kept by the author.

- Toš, Niko et al. Slovensko javno mnenje 1986 [database]. Ljubljana: Univerza Edvarda Kardelja, Fakulteta za sociologijo, politične vede in novinarstvo, Center za raziskovanje javnega mnenja in množičnih komunikacij [creation], 1986; Ljubljana: Univerza v Ljubljani, Fakulteta za družbene vede, Arhiv družboslovnih podatkov [distribution], 1999.

- Toš, Niko et al. Slovensko javno mnenje 1989: Stališča o ustavnih dopolnilih [database]. Ljublja- 
na: Univerza Edvarda Kardelja, Fakulteta za sociologijo, politične vede in novinarstvo, Center za raziskovanje javnega mnenja in množičnih komunikacij [creation], 1989; Ljubljana: Univerza v Ljubljani, Fakulteta za družbene vede, Arhiv družboslovnih podatkov [distribution], 1999.

- Ustava Socialistične republike Slovenije.

- Vrednote v prehodu VIII: Slovenija v srednje in vzhodnoevropskih primerjavah, edited by Niko Toš. Ljubljana: Univerza v Ljubljani, Fakulteta za družbene vede, IDV - CJMMK; Wien: Edition Echoraum, 2014.

- Zakon o volitvah in delegiranju v skupščine: Zakon o volitvah in odpoklicu Predsedstva Socialistične republike Slovenije s pojasnili Cirila Ribičiča in Franca Grada. Ljubljana: ČZ Uradni list SRS, 1985.

\begin{tabular}{c} 
Jure Gašparič \\
\hline SLOVENSKI SOCIALISTIČNI PARLAMENT NA PREDVEČER RAZPADA \\
JUGOSLOVANSKE FEDERACIJE - BLEDO “RATIFIKACIJSKO TELO” ALI VAŽEN \\
POLITIČNI ODLOČEVALEC? \\
\hline P O V ZE T E K
\end{tabular}

Avtor ugotavlja, da socialističnemu parlamentu na predvečer razpada Jugoslavije doslej ni bilo posvečene veliko raziskovalne pozornosti; to velja tako za republiške skupščine kakor za zvezno skupščino v Beogradu. Toda (to lahko trdimo za Slovenijo) skupščina je v tem času doživljala notranje spremembe in zlasti sprejemala važne odločitve; v procesu razgradnje jugoslovanskega federalizma je bila ustavni in politični faktor, ki ga ni bilo mogoče zaobiti. Slovenska skupščina je tako med drugim septembra 1989 sprejela številne ustavne amandmaje k republiški ustavi, ki so uvedli večstrankarski sistem, elemente tržnega gospodarstva in okrepili položaj republike. Zdi se, da je nenadoma postala prvi in odločilni politični faktor. Toda take ocene republiške skupščine ni nikjer najti. Ob zapleteni sestavi, ki je temeljila v delegatskem sistemu iz leta 1974, ostaja skupščina precej zagoneten faktor zgodnje tranzicije. Izhajajoč iz tega se zato avtor v prispevku sprašuje, kakšen organ je skupščina sploh bila? Pri tem najprej predstavi genezo jugoslovanskega skupščinskega sistema in njegove temeljne značilnosti, nato pa obravnava tri različne ravni oz. možne poglede na skupščino. Najprej pravno raven, kjer ugotavlja, da je skupščina imela vse sistemske pogoje za to, da dejansko opravlja važno politično vlogo v sistemu. Brez njenega angažmaja politične spremembe ne bi bile mogoče, vsaj ne po ustavni poti, ki je bila značilna za slovenski osamosvojitveni proces in prvo fazo politične tranzicije. Nato analizira raven dojemanja skupščine med prebivalstvom, kjer meni, da je skupščina septembra 1989 dejansko bila predstavniško telo, udejanjala je politično voljo prebivalstva. Ob koncu se loti še ravni notranjih mehanizmov, saj s pomočjo orodij digitalne humanistike pogleda nekatere kvantitativne kazalce parlamentarne razprave. Iz teh se vidi, da je politična dinamika, ki jo je bilo čutiti povsod po Sloveniji in Jugoslaviji, zašla tudi v skupščino in zaznamovala njeno delo - govorilo se je več.

Skupščina je torej tedaj bila legitimno telo, a je vprašanje, s čim je svojo legitimiteto pridobivala. Po eni strani vsaj deloma s korakanjem k svojemu koncu, s sprejemanjem sklepov, ki so pomenili spodkopavanje sistema. Toda po drugi strani je bržkone njeno legitimiteto in zaupanje med ljudmi vsaj v enaki meri (če ne večji) dvigala grožnja, ki so jo ljudje videli v Beogradu. Z institucijami federacije, vključno z Zvezo komunistov Jugoslavije, je bila situacija drugačna, vse bolj so bile same sebi namen. Njihova legitimnost je sčasoma povsem usahnila. Kredibilnost slovenske skup̌̌čine se je medtem le še krepila, zlasti po aprilu 1990, ko so bile prvič po letu 1927 izvedene večstrankarske in tajne volitve. V skupščino so tedaj sedli delegati, ki so se navkljub veljavni ustavi novim časom primerno nazivali z izrazom poslanci. Med njimi je bil največ članov novih strank, a velja opaziti, da je tudi nekdanja Zveza komunistov Slovenije z drugimi bivšimi družbeno-političnimi organizacijami osvojila zelo dober rezultat. Slednje morda lahko interpretiramo kot dodaten argument, ki govori v prid tezi, da je bila bivša socialistična skupščina v zadnjem obdobju vendarle legitimna "predstavniška” ustanova, blizu prebivalstvu. 